\title{
Social Capital and Household Welfare Among Anioma People in Delta State, Nigeria
}

\author{
Dr. Chris ‘E Onyemenam \\ Lecturer, Department Of Sociology And Anthropology \\ Baze University, Abuja, Nigeria
}

\begin{abstract}
Most studies on social capital and household welfare have focused largely on econometric analyses of formal networks while informal, less institutionalised but durable networks are either ignored or concepts like 'trust', and 'age groups' are reduced to equations in econometric models that leaves out the quintessential social aspects. This non-econometric study focused on informal networks and social relations, using ethnographic and cross-sectional survey data from 13 homogenous Anioma communities in Delta State, Nigeria. Descriptive and inferential statistics were used to analyse the primary data while content analysis was used for the ethnographic data. Among others, the study found that access to social capital was not gender sensitive, it was not significantly related to welfare but it is positively correlated with household per capita income. Finally, while there was a large stock of social capital, household welfare remained low, due to the high level of poverty and the influence of the communal value that places an obligation on those who have more than others to help, such that they become 'drawn back', by their stock of social capital, which becomes an encumbrance of a kind. Accordingly, government should invest in informal social capital and incorporate it in its development policies and implementation plans, so as to help remove the 'draw backs,' foster healthy relations between community-level organisations and kinship-based networks and involve both types of social capital in its pro-poor programmes.
\end{abstract}

Key words: social capital, household welfare, informal networks, social relations, ethnographic data.

\section{INTRODUCTION}

The collapse in oil prices in 2014 - 2016, one of the largest in modern history, which unexpectedly failed to provide a boost to global economic growth, adversely affected crude oil exporting countries, Nigeria inclusive (World Bank 2018). So their economic growth and development slowed down, poverty levels rose and with the advent of the Millennium development Goals (MDGs) (and the successor programme - the Sustainable Development Goals, SGDs) most countries have now made poverty reduction a primary objective of development including Nigeria that, it would seem, has only recently come out of a rather selfinflicted economic recession (NBS, 2017). The shift in emphasis from a 'human development' perspective (UNDP, 2015) to a 'people perspective', has brought into sharp focus sustainable social development issues - transformation in attitudes, institutions, capacity (and access) to meet basic human needs, quality of life and ability of the poor to influence processes that shape their lives and efforts at helping them out of poverty (UNDP, 2016, World Bank, 2018). Analyses of factors in the development process have thus transcended the traditional approaches that hinge on econometric analysis of 'core assets' - physical, human, natural, technological, financial and even entrepreneurial capital (Ismawan, 2000, Balogun \& Yusuf, 2011). In the odd case of Africa, wrongly reinforced by the nebulous and questionable claim of significant value addition, is the 'development aid to Africa' factor, which, as recent reports show, accounted for no more than 2\% of gross domestic product (GDP) of growing African economies (World Bank, 2018). The basic assumption was that to fight poverty and foster 
'bottom-up' led sustainable development, improved access to 'core assets' by poor households was vital.

But empirical evidence from developing, transitional and developed economies contradict this view, and suggests that differences, whether at the level of the individual, household, community or state, cannot be fully explained by differences in 'core assets'. Indeed, noneconomic factors like social capital, defined simply as 'the ability of actors to secure benefits by virtue of membership in social networks or other social structures' (Portes, 1998), play an important role. Studies on the impact of social capital on the well being of poor rural households have often focused more on econometric analysis of formal (organisational) social capital with inadequate attention to 'informal social capital (Onyemenam 2017). A noneconometric study of informal social capital will facilitate a deeper understanding of how households are able to secure enduring levels of well being over time and thus provide useful insights on how to design 'people friendly', 'participatory', and 'bottom-up' led social development policies and implementation plans. It will broaden the scope of analysis to cover what most researchers with economic background have unwittingly ignored or failed to adequately capture through the incorporation of the 'social dimensions' of 'capital' into the analyses of the 'development equation', within the sustainable social development paradigm.

\section{Statement of The Problem}

In most rural communities in Nigerian and sub-Saharan Africa, traditional factor inputs are relatively scarce or increasingly depleted, resulting in pervasive and extreme poverty. It is particularly so where farming is largely subsistent and non-mechanised. In such a situation, social capital may potentially be accessed to substitute or augment existing forms of capital to improve household welfare. Often, individual households engage in kinship, communal or civic activities to enable them leverage the benefits that such membership affords, in their fight against poverty. The community's social history is often reflected in its social structure, especially the informal/kinship groups, cultural norms, beliefs, trust and value systems, etc. which are critical to how informal social capital is formed and appropriated by households. Because of Nigeria's ethnic, socio-cultural diversity and historical experience, communal and civic engagements may be determined by accident or disaster, immediate need or situation, personal goals, communal and or collective interest, circumstances of social history, ethnic antecedents, or sentiments etc. Indeed, such engagements might end up in a positive or negative impact on household welfare, since all actors possess different benefit capacities and not all networks and social relations represent the same or similar possible outcomes for different persons - to some, 'welfare enhancing' and 'constraining', to others. There might be some other factors or contexts that distort, obscure, suppress, intervene or veil the nature of the outcomes or relationship especially in the household's 'social milieu as mediated by the community's social history.

In spite of the 'social' nature of social capital, most studies in Nigeria have focused on the econometric analyses of formal, community-level, organisational social capital and the rural poor (especially farmers). Consequently, sociological concepts like 'trust', 'norms', 'kinship' and 'peer' groups, though difficult to measure in the field, are reduced to equations and subjected to econometric modelling that leaves out the quintessential social aspects. Conclusions reached on this basis are therefore inadequate, to say the least. Informal yet durable networks and social relations are an integral part of a community's social structure, which impact poor rural household social milieu significantly. The resources embedded in them are vital to the enhancement of their welfare and in particular, how they respond to government's poverty intervention efforts. Consequently, due to the susceptibility of households, informal networks, 
social relations and the social milieu to the enabling, intervening, or constraining factors in the community social structure there is need for a refreshing empirical investigation of the relationship that is not grounded in Economics, in view of the dearth of empirical studies in Nigeria on the role of such informal networks and social relations on the welfare of rural poor households. Incorporating ethnographic data, as in this study of the Anioma people in Delta State in Nigeria, seeks to extend the frontiers of knowledge on household welfare, community development and poverty reduction strategies in Nigeria.

\section{The Research: Aim, Questions and Significance of Study}

The aim of this study was to investigate and validate the nature of the relationship between social capital and household welfare among the Anioma people in Delta State, Nigeria with special attention given to informal social capital. Specifically, they included: examine the relationship between gender of head of household and access to social capital, determine the relationship between social cohesion and inclusion and household welfare, investigate the relationship between social network and household welfare; explain how the household's stock of social capital is appropriated to impact its welfare and assess the relationship between social capital and household per capita income.

The central concern is encapsulated in the research questions formulated to guide the study, like, what is the relationship between gender of head of household and access to social capital? What is the relationship between social cohesion and inclusion and household welfare? What is the relationship between social network and household welfare? How is the household stock of social capital appropriated to impact its welfare? What is the relationship between social capital and household's per capita income?

Five research hypotheses guided the study namely:

i. There is a relationship between the gender of head of household and access to social capital;

ii. Households with high income are more likely to benefit from high social cohesion and inclusion;

iii. Social network is correlated with household welfare;

iv. There is a relationship between a household's stock of social capital and its welfare;

v. There is a relationship between social capital and household per capita income.

The study provides useful evidence-based insights on policy-making options/solutions to the development challenges in Nigeria. It offers deeper understanding of the differences between and how community organisations and kinship groups can be strengthened towards effective mobilisation of the rural poor to participate in the design and implementation of development projects at the community level. Also significant is the conceptual framework espoused, innovative analytical approach adopted and because the study is grounded in Sociology and Anthropology, a departure from previous studies that were mostly in Economics. It is an important addition due to the paucity of empirical studies on (and draws attention to hitherto ignored aspects of) informal social capital.

\section{Social Capital and Household Welfare}

As a heuristic device, 'social capital' is a ragbag word that captures the productive benefits of social relations and networks. As Narayan \& Woolcock, (2000) put it, 'it's not what you know, it's who you know', social capital is the 'lubricating fabric of society', an important form of capital, the 'glue' that holds all the other forms of capital together (World Bank, 2001). The literature reflects a variety of perspectives informed mostly by the background and research interest of the person providing the definition (Putnam, 2001, Vitolas, 2011) and as Portes 
(1998) puts it, 'whereas economic capital is in people's bank accounts and human capital is inside their heads, social capital inheres in the structure of their relationships'. It is embedded in the social structure and systems, the 'core' of 'communal assets' (Lin, 2001, Bourdieu, 1985), and as an idea, dates back to the history of socioeconomic thought, especially in the works of De Tocqueville, Durkheim and Marx (Halpern, 2005, Putnam, 2001).

Most studies have used econometric models to investigate the impact of organisational social capital on expenditure, consumption or income and household welfare - Probit Regression Analysis (Hu \& Jones, 2004), Logistic Regression Analysis (Kumar, 2015), Linear Probability Analysis (Akinleye \& Majekodunmi, 2012) and Ordinary Least Square Estimation Technique (Rustiadi \& Nasution, 2017). However adequate attention was not given to informal social capital because most studies stemmed in part from the household 'asset endowment' assumption that did not include 'social capital' in the production function since it was not considered 'capital' enough to merit any significant consideration (Onyemenam, 2017). That has since changed. Earliest studies especially from the 1990's focused on proximate measures like 'voluntary associations', 'peer groups', features of community life, etc. (Knack \& Keefer, 1997) (Putnam, 1993), economic performance and impact of poverty reduction strategies (Tendler, 1997, World Bank, 2001). More recent studies confirmed the positive role of social capital on household welfare through its impact on income, expenditure and consumption (Idris \& Agbim, 2015, Olawuyi \& Olawuyi, 2015). The typical modelling approach starts with a set of structural equations that stipulates the conventional household's economic behaviour under constrained utility maximization, which is then used to evaluate the impact of social capital on household welfare (Narayan \& Pritchett, 1999, Atemnkeng, 2009). This model, when adjusted to incorporate social capital and the economic setting of household decision-making, in terms of poverty reduction and sustainable human development, operates to establish the social capital-poverty nexus, the context that gives social capital its importance in explaining differences in development outcomes (Onyemenam, 2017).

When the State is unable to meet its obligations to the citizens, community-level organisations and voluntary associations have emerged to fill the gap (De Tocqueville, 1994), underscoring the inherent failure of the State to foster popular empowerment of the citizenry in the development process (Ninalowo, 2007, 2010). Social networks, formal or informal, have been known to positively impact household welfare through various membership benefits (Atemnkeng \& Vukenkeng 2016, Rustiadi \& Nasution, 2017) like access to 'uncollateralised' micro credits (Anyiro \& Ajuka, 2014) especially from formal financial institutions (Anyiro, 2015, Olawuyi \& Oladele 2012, Anyiro, Ezeh \& Emerole, 2014), particularly women’s groups (Anyiro, Ajuka, Emerole, \& Orji, 2014, Sama, Chiatii, Aquilas \& Abit, 2016) and alleviation of poverty among women entrepreneurs (Idris \& Agbim, 2015). Yusuf (2008) used the single structural social capital index consisting of six measures, namely, density of membership, internal heterogeneity of associations, meeting attendance, payment of membership due, labour contribution, and decision-making to show how these components of social capital impact household welfare. Hu \& Jones's (2004) study of the Iteso rural households in Eastern Uganda, found that there was no significant relationship between organisational social network and household welfare due to factors embedded in the social history of the people, which explained the positive impact of informal networks and social relations on household welfare.

Socioeconomic characteristics were found to be positively related to aspects of social capital, in particular age, (Ijioma \& Osondu, 2015)), sex gender, (Asa \& Archibong, 2016), household size, (Abdul-Hakim, Ismail \& Abdul-Razak 2010), level of educational attainment (Olawuyi \& 
Olawuyi, 2015) marital status (Akinbode \& Hamzat 2017) and farming status, (Adepoju \& Oni 2012). However, Olawuyi \& Oladele (2012) found that sex gender of the head of household was not significantly related to social capital, while Hu \& Jones (2004) found that sex gender did not affect access to social capital. Households' income per capita (measured by monthly estimates from survey data) is positively related to welfare (Baiyegunhi 2013) and households with a higher number of 'working members' was found to be better off (Akinleye \& Majekodunmi 2012). Also, households with high social capital have higher expenditure per capita, better access to credits, higher savings and are positively correlated with household welfare (Kumar 2015).

Organisational social capital significantly influence the rural households' access to and amount of credit facilities available from different sources (Balogun, Yusuf, Omonona \& Okoruwa, 2011), and Caarl, Fransen \& Ruben's (2013) study confirmed the positive impact on welfare, of remittances on beneficiary households, particularly in urban areas. Remittances are a type of extra income, which flowed through informal channels - hand deliveries and couriering within family networks based on trust and solidarity (Fransen, 2015). Remittances were found to increase bridging social capital investment in community-level organisations and similar activities of remittance-receiving households. These studies viewed the positive impact of migration, by a member of the household as rural households' strategy to generate extra income through home remittances that subsequently impact household welfare positively and serves as an insurance against financial shocks, other forms of disaster and for investment purposes.

The worsening poverty situation in Nigeria, especially in the rural areas, in spite of decades of huge spending on pro-poor programmes by both the federal and state governments, have raised concerns as to the efficacy of these efforts and given credence to the theory, though inconclusive, that the rural poor households embrace social capital as a strategy to fight their way out of poverty (Onyemenam, 2017). Over 60\% of Nigeria's estimated 190 million people are poor, up from 54\% recorded in 2010 (NBS, 2011, 2017). And as Okunmadewa, Yusuf \& Omonona, 2005) pointed out, the failure and or limited successes recorded is attributable to non-participation of the poor in the design and implementation of the pro-poor programmes due in part to the absence, or where they exist, weak institutional mechanisms for mobilising their involvement. Similarly, most studies in Nigeria have focused on econometric analysis of dimensions of community organisational social capital, especially rural poor households' membership in associations (Anriyo, 2015, Ijioma \& Osondu, 2015, Olawuyi \& Olawuyi, 2015) leaving out the quintessential social aspects that are embedded in the informal networks and social relations and thus an incomplete evaluation of the impact of social capital on the welfare of rural poor households.

\section{Theoretical Framework}

A socio-ethnographic framework, a departure from previous approaches is adopted. The framework, an adaptation of Este's (2004) 'social capital mix', posits that there are three core institutions of society namely, the 'Market,' the 'State,' and the 'Family/Household,' each with its role and 'contributing' to the web of dense networks and social relations within the society's public space and the source of social capital available to and appropriated by the poor rural households. Civil society or community organisations are seen as operating in an uncharted part of the public space, an intermediate area rather than a clear-cut sector or as a core institution. They are 'polyvalent' entities with widespread social capital resources within the society. As hybrids, 'intermeshing' resources from core institutions and the interstices between them, they play the role of 'promoting' a synergetic mix of such 'capitals' within the resulting wider social milieu and hence the concept of social capital mix. But the informal, less 
institutionalised networks and social relations embedded in the community's social structure and history is also important and should be adequately incorporated into the 'social capital mix'. That is, a household's mediated access to this type of resources ('informal social capital) can impact its welfare such that reducing them to equations in an econometric model is clearly inadequate.

Consequently, this framework juxtaposes, within a wider social milieu, the potential sources of social capital benefits available to rural poor households in their fight against poverty - the formal (such as government poverty intervention, markets, civil society and community-level organisations and their programmes) and the informal networks and social relations (such as 'kinship', 'peer' groups, 'interpersonal trust' and 'norms' - admittedly, sociological terms that are difficult to measure in the field. However, this difficulty is addressed by a careful attention to survey work, useful insights from the social history and community social structure of the household, with the incorporation of existing ethnographic data. Therefore, the prevalent form and option of social capital appropriated by the household (and therefore the impact on welfare) are mediated by factors in the wider social milieu, symbolised by the social capital mix and the social characteristics of the community. In this way, both types of social capital are incorporated into the framework to give a complete picture and facilitate a holistic contextual analysis that obviates the benevolent abandonment of the 'central role of culture' in the process of formation and appropriation of social capital (Greif, 1994) among the poor rural households to enhance their welfare and break the vicious poverty circle This is captured in the conceptual schema in figure 1.

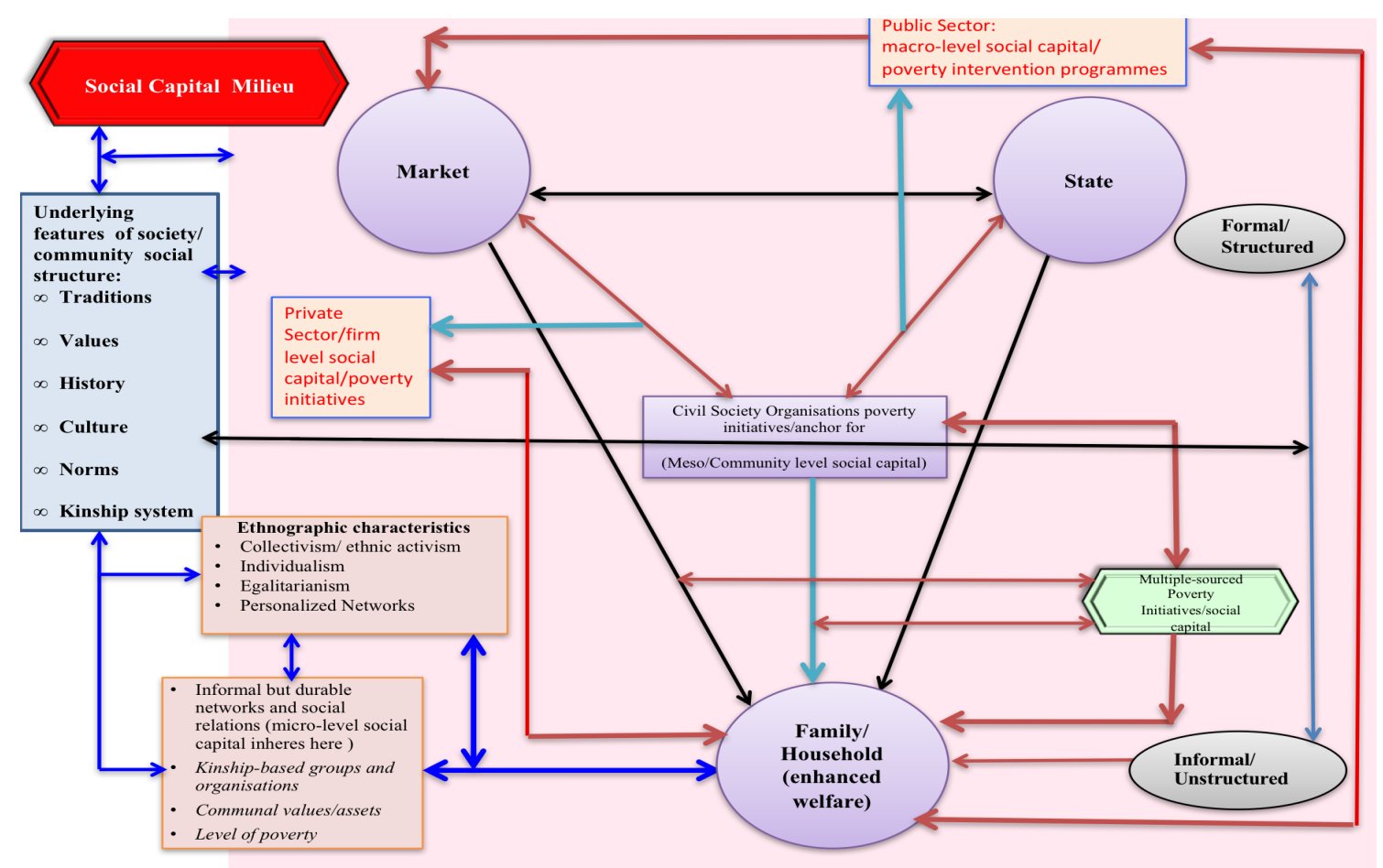

Figure 1: Social Capital Mix showing the relationship between core institutions of society, civil society, formal/informal social capital, community social characteristics and household welfare (Onyemenam, 2017), adapted from Estes, (2004).

\section{METHODOLOGY}

The study adopted a cross-sectional survey research design and used a mixed method approach that included the administration of a questionnaire, in-depth interviews, focused group discussions and the use of existing ethnographic data, informed by the research 
questions and stated hypotheses. The study was carried out in 9 of the 25 Local Government Areas (LGAs) in Delta State, Nigeria, among the Anioma people, some 160 Igbo-speaking communities made up of 4 sub-divisions - Aniocha, Ndokwa, Ika and Oshimili. The name 'Anioma' is an acronym for these sub-divisions. They are one of the five major ethnic groups in Delta State, others are Ijaw, Isoko, Itsekiri, Urhobo. The study area is in the West Basin of the River Niger in Delta State (Ohadike, 1994, 1991,0sia, 2012). The population of the Anioma people is a total of 1,229,371 persons (620,517 males and 608,854 females) in 279,063 households (NPC 2007). They are mostly Christians and Traditional African Religionists. Traditional social life is based on obligatory membership (by birth or initiation) of kinship groups and parallel but complementary dual-sex associations, and social groups (Isichei, 1973, Osia 2012). The study area offers a fairly homogenous group of communities who trace their common history to the same origins and ancestors, with similar culture, language, religion, traditions, beliefs, kinship and value systems and reside in a geographically contiguous, welldefined administrative and political space in Delta State. Besides, there is also adequate ethnographic and anthropological data on the Anioma people, which provides useful insights on their social history and makes isolation of the population possible for the purpose of the study.

A multi-stage sampling technique was used to select 13 communities and the sample units that were finally selected. Of the planned sample size of 1,676 - about $10 \%$ of the population of the communities - 1,392 responded (83\% response rate) consisting of 3 categories - male and female household heads resident in the communities, leaders of community-level organisations and the heads/leaders of the selected communities. In the case of female household heads, the snowball technique was used to reach additional respondents. The Statistical Package for Social Sciences (SPSS) was used to process the survey data while content analysis was used for existing ethnographic data on the Anioma people.

\section{Measuring Social Capital, Household Welfare}

The key indices - 'social capital' and 'household welfare' were measured by a composite index approach. A 'Social Capital Index' was created and measured by using an aggregative sevencomponent method, namely: 'Groups and Network', 'Trust and Solidarity', 'Social Cohesion and Inclusion', 'Collective Action and Cooperation', 'Source of Information and Communication', 'Conflict and Violence', and 'Empowerment and Political Action' (World Bank, 1999, Grootaert, 1999, 1998). A set of questions with scaled responses (using the Likert scale of 1-5) on each component was used to grade and put each respondent into one of three groups - 'low', 'medium', and 'high'. The summation of each respondent's score on each of these components was then used to determine the final groups, which was in two categories of 'low' and 'high' social capital. This composite index was computed using the seven dimensions of organisational social capital by Narayan \& Pritchett, $(1997,1999)$, albeit for comparative and referential purposes. For the 'household welfare index', the components were access to 'education', 'health services', 'water supply and sanitation', 'credit/savings schemes', 'agricultural services', 'travelling opportunities' and 'family support'. A similar process was also followed to construct a 'household welfare index' with two categories based on a total possible score from '1' to '8'. Scores of '1' - '4' was categorised as 'low household welfare', and scores of '5' - '8' was categorised as 'High household welfare'.

\section{DATA SET: ETHNOGRAPHIC DATA}

Available data on the social history of the Anioma people reveal five important social characteristics that play a critical role in the formation and appropriation of informal social capital and its impact on household welfare (Ohadike 1994, 1991, Osia, 2012). They have a long history of cultural beliefs and values that suggest it will take a long time to change, and 
although nurtured social capital, also constrain its appropriation towards improvement of poor rural households' welfare among the Anioma people. First, is their peculiar social milieu. They are an amalgam of immigrants from four 'history of traditions' of 'origin', who trace their founding fathers to the Igboland in the East of the Niger, Benin, Igala and the Yoruba land in Nigeria. They ostensibly accepted each other, sought understanding, mutual respect, cooperation and peaceful co-existence. Over time and generations of socialisation through cultural belies and values were communiacted, they developed strong cross-cultural relations and deep social bonding that thawed their different migratory backgrounds, moulded them into a homogenous group of communities sharing similar socio-cultural, political, economic and communal values long enough to identify themselves as an 'ethnic group' - 'ndi enuani', or 'ndi anioma' (Osia, 2012, Ohadike, 1994, 1991).

The second is 'collective ethnic activism' - a strong sense of altruism, 'spirit of oneness' and ability to build 'consensus' along ethnic lines among them that dates back to their founding fathers - which flows from their similar community social structure and history. Whatever subethnic differences or 'communal identity' melts off instantaneously for the wider 'Anioma' ethnic-group interest. This activism or 'capacity for group action' is located within the lineage system, but 'builds-up, outwardly, in concentric circles', from the smallest unit, the 'uno' (family), to the 'umunna' (extended family), 'eboh' (group of extended families), 'ogbe' (group of 'ebohs'), 'obodo' (extended group of 'ebohs'), to the 'village' or 'town', sub-ethnic and then the whole of 'Anioma' communities. This trait owes its enduring influence in part, to two historically significant developments: the social bonding, based on trust and solidarity, common migratory background, ancestry and history of sorting out how to live together as a people that dated back to pre-colonial times. Second, how they mobilised 'group action' against two wars: during the 'self-liberation' wars - the 'white man Iredi (Crewe Reed) that lasted 6 years and their resistance of British imperialism for over 31 years before their conquest in the 'Ekumeku War of Resistance in 1914 (Ohadike, 1994, 1991); and the Asaba and Isheagu (male) massacre during the Nigeria civil war, 1967-1970 (Okocha, 2006), which led to a historic distortion of their demographics and caused an unprecedented single (female, head of household) parenthood. In spite of this, kinship networks and informal social relations and the cultural and communal values that impose an obligation on those who have more than others, to give - 'be thy brothers' keeper' - endured and served as springboard for providing assistance, sharing grief, mourning the dead, rebuilding families, providing assistance and generalised social anchorage during and after such wars. They became invariably more reliable, easily preferred and part of their cultural DNA.

The third, 'individualism', depicted them as very personal in their approach to networking and social relationships. Partly due to their migrant background and as mostly farmers, they are driven by status-seeking desire to achieve the 'manhood' criteria set by the community that included qualification for marriage or taking a traditional and or social chieftaincy title, etc. Similarly the women folk have their own set of criteria. This personalised approach 'spirals' out from the nuclei family, in similar centric patterns to various levels and types of kinship and social groups within the communities. Often, this resulted into unhealthy rivalry, conflicts and a 'clash of hierarchy' where, for example, the head of a community organisation might not be a chief or is 'less successful' in the community than an ordinary member who is a chief and more 'successful' - such persons are often readily disposed to reject or question actions and even the legitimacy and authority of the leadership of the organisation (Ohadike, 1994, Osia, 2012).

The fourth, the way networks are personalised by individuals and households, in terms of how they establish social relations outside their immediate 'ogbe' or 'community', independent of 
formal organisations, and even sometimes kin groups. Usually, it is in response to difficulties in accessing or constraints of weakness in obtaining assistance from existing networks or simply to obviate the seeming stranglehold of cultural values on them. So individuals typically link up with a relative, friend or peer group far away, for some form of assistance (aside from a church, civil society organisation, etc.). In recent times, various forms of home remittances and monthly support allowances from these sources have become a significant source of income and welfare improvement for the rural poor in the Anioma area.

Finally, the egalitarian nature of these communities in terms of the way individuals - men (and women alike) see themselves first as equal to all other men. Among the people, the maxim is that every one has the right of individual equality, which must be respected, even if he is not successful or does not hold any title. Thus the head of a household will be accorded the due respect, no matter his age, or gender only. The traditional injunction that aptly captures this is 'okpala ka eze', literally translated, means the head of the family (determined by age), is superior to any traditional title, or position held by anyone. Similar conflict and 'clash of hierarchy' - between holders of positions in formal community-level organisations and informal kinship groups is experienced - since people who like being treated equally often bring to bear on the conduct of formal organisations, their position in the kinship groups' hierarchy and vice versa with its inherent potential for breeding dissent and conflicts of different types.

All these social characteristics impact how social capital is created and utilised and define the nature, quality, quantity and level of access to each type of social capital and the resulting impact on welfare. The influence of kin groups is underscored by the deep attachment to cultural values, the obligations they impose on individuals, to observe them and avoid sanctions - the corresponding weakened interest in community-level organisations it engenders. The often reported preference for community-based group actions to provide, for instance, scholarships and educational support, (Osia 2012, Ohadike, 1994) epitomise how they appropriate the immense resources embedded in the kinship network, which characterise their social history and cherished values even when obligations of 'being your brother's keeper' were extremely tasking. The 'egalitarian' cum 'equality dilemma', more than reveal the grip of cultural and kinship values on individuals/households, and the resulting conflicts have always been resolved in favour of kinship hierarchy.

\section{Survey Data: Socioeconomic Characteristics}

There is no significant sex gender difference - $49 \%$ males, $51 \%$ females (in a largely patrilineal group of communities). The age structure (see table 1) suggests a relatively 'young-to-mature' population (18 - 60 years). Most of the respondents fall within the age group of 25 - 59, accounting for $72.9 \%$, largely, the 'labour force' group. About $27 \%$ have primary education while another $49 \%$ have junior/senior secondary education. The predominant economic activity is subsistence 'farming and fishing' (32.8\%), followed by 'trading' (22.2\%) - two activities especially at the subsistence level that require no significant level of educational attainment. The oil-rich nature of the Anioma economy is 'external' to the local economy/indigenes. Income, measured by respondent households' estimated monthly income, fluctuates with most (53.8\%) falling within the broader category of N20,000.00 to N60,000.00, 20.2\% earn between N30,001.00 - N40,000.00. Household size (table 2) is 'medium to large', averaging 4 - 8 persons,

Table 1: Socioeconomic and Demographic Characteristics

\begin{tabular}{|l|l|l|}
\hline Socioeconomic and Demographic Characteristics & Frequency (N) & Percentages (\%) \\
\hline Age Group & & \\
\hline
\end{tabular}




\begin{tabular}{|c|c|c|}
\hline $\begin{array}{l}<18 \\
18-24 \\
25-34 \\
35-44 \\
45-49 \\
50-59 \\
60-\text { Above } \\
\text { Total } \\
\end{array}$ & $\begin{array}{c}110 \\
121 \\
204 \\
298 \\
287 \\
208 \\
138 \\
\mathbf{1 3 6 6} \\
\end{array}$ & $\begin{array}{c}8.1 \\
8.9 \\
14.9 \\
21.8 \\
21.0 \\
15.2 \\
10.1 \\
100 \\
\end{array}$ \\
\hline \multicolumn{3}{|l|}{ Educational Attainment } \\
\hline $\begin{array}{l}\text { No formal education } \\
\text { Primary } \\
\text { Secondary (JSS) } \\
\text { Secondary (SSS) } \\
\text { Tertiary (OND/NCE) } \\
\text { Tertiary (HND, degree/PG) } \\
\text { Total }\end{array}$ & $\begin{array}{c}225 \\
369 \\
184 \\
348 \\
44 \\
196 \\
\mathbf{1 3 6 6} \\
\end{array}$ & $\begin{array}{c}16.2 \\
27.0 \\
13.5 \\
25.5 \\
3.2 \\
14.3 \\
\mathbf{1 0 0}\end{array}$ \\
\hline \multicolumn{3}{|l|}{ Occupation of respondents } \\
\hline $\begin{array}{l}\text { Clergy } \\
\text { Farming/fishing } \\
\text { Trading } \\
\text { Civil services } \\
\text { Student } \\
\text { Artisan } \\
\text { Politician } \\
\text { Pensioner } \\
\text { No response/others } \\
\text { Total } \\
\end{array}$ & $\begin{array}{c}89 \\
448 \\
303 \\
99 \\
128 \\
57 \\
44 \\
58 \\
150 \\
1366 \\
\end{array}$ & $\begin{array}{c}6.5 \\
32.8 \\
22.2 \\
7.2 \\
9.4 \\
4.2 \\
3.2 \\
4.2 \\
10.2 \\
\mathbf{1 0 0} \\
\end{array}$ \\
\hline \multicolumn{3}{|l|}{ Monthly estimated income } \\
\hline $\begin{array}{l}<12,001-15,000 \\
15,001-17,000 \\
17,001-20,000 \\
20,001-30,000 \\
30,001-40,000 \\
40,001-50,000 \\
50,001-60,000 \\
60,001-\text { Above } \\
\text { No response } \\
\text { Total }\end{array}$ & $\begin{array}{c}56 \\
35 \\
158 \\
112 \\
276 \\
133 \\
215 \\
113 \\
268 \\
1366\end{array}$ & $\begin{array}{c}4.1 \\
2.6 \\
11.6 \\
8.2 \\
20.2 \\
9.7 \\
15.7 \\
8.3 \\
19.6 \\
100\end{array}$ \\
\hline
\end{tabular}

Source: Onyemenam; (2017).

(82.9\%). Generally, there are more males in each household category than females (with female estimated monthly income being $14.7 \%$ lower than that of males). In most households, at least 2 persons are in school and 2 are gainfully employed, an indication of regular income and a predisposition to membership of certain types of association. Most households (over $75 \%$ ) receive remittances of between N10,000.00 and N30,000.00 (another 10\% say they get between N30,001.00 and N40,000.00). Households belong to one group or the other - both informal and formal - however most of them belong (table 3) to ethnic/family/age groups (71.5\%). There is a strong preference for formal organisations, which is progressively indicated (from 68.6\% upwards, in table 4), the most preferred being 'cooperatives' and 'traders associations' (90\% and 81\%), followed by town union/Youth/Age-grade associations (79.6\%), political groups, religious and farming/fishing associations (75\%, 73.5\% and 72\% respectively). Membership of informal groups is indicative of the strong attachment to cultural values. The preference for 'women's group,' that showed a number slightly higher than the total female respondents in the study 
Table 2: Respondents by Household Composition and Structure

\begin{tabular}{|l|c|c|}
\hline Components of Household composition & Frequency & Percentages (\%) \\
\hline Number of persons in the household & & 16.4 \\
\hline Up to Four & 224 & 15.2 \\
Five & 208 & 23.5 \\
Six & 321 & 19.3 \\
Seven & 263 & 8.6 \\
Eight & 117 & 4.1 \\
Nine & 56 & 4.1 \\
Ten & 56 & 8.9 \\
No response & 121 & 100.0 \\
Total & 1366 & 1.2 \\
\hline Number of persons in school & & 37.2 \\
\hline One & 17 & 19.8 \\
Two & 508 & 7.6 \\
Three & 271 & 14.9 \\
Four & 104 & 4.1 \\
Five & 204 & 15.1 \\
Six & 56 & 100.0 \\
No response & 206 & \\
Total & 1366 & 47.6 \\
\hline Number of persons gainfully employed & & 18.7 \\
\hline Two & 650 & 6.8 \\
Three & 255 & 6.5 \\
Four & 93 & 1.1 \\
Five & 89 & 6.4 \\
Six & 15 & 4.1 \\
Seven & 87 & 100.0 \\
Nine & 56 & \\
Not gainfully employed & 121 & \\
Total & 1366 & \\
\hline
\end{tabular}

Source: Onyemenam, 2017

is because some male respondents actually picked 'women's groups as very important due to their wife's active involvement and because they felt more, the impact of household benefits they derived. Membership in formal groups is by registration (56.3\%), with introductions often by an existing member. In most formal organisations, level of educational attainment, age, marital status, and occupation are important criteria. In kinship groups however, being an indigene, marital status date of birth (age groups), initiation, membership ceremonies and such other activities that evoke primordial sentiments and attachment to traditions and culture, which reinforce social history and ancestral origin, play a significant role. Most respondents (71.5\%) belong to 'ethnic/family' based groups (table 3 ) and the corresponding predisposition towards benefits from this source is consistent with the ethnographic finding of their 'bonding', 'collective' and 'consensual' orientation, aptly captured by the idiom anyi bu ofu nne, which literally means, 'we are of one mother'. Membership of informal networks did not show much stratification unlike in formal associations where membership criteria stratify persons severally - income, qualification, registration fees paid, annual dues, end of year parties, venue for meetings, etc. These criteria shape households' pre-disposition to a specific source of assistance/help. It is reasonable to expect that households are more likely to belong to groups or networks of their ethnic extraction than others (table 3). For example, 'Anioma Forum', a strong pan-Anioma peoples' socio-cultural and political organisation is generally less fancied (54.8\%) than traders association (81\%, farming/fishermen groups (72\%), 'town unions' $(79.6 \%)$, credit/savings groups $(68.6 \%)$ or village associations, $(66.8 \%)$, which are mostly 'ethnic or kinship based groups (table 4). 
Table 3: Households Membership of Groups and Networks

\begin{tabular}{|l|l|l|l|}
\hline S/N & Type of Group/Network & Frequency & Percentage (\%) \\
\hline 1 & Occupational Group & 327 & 23.9 \\
\hline 2 & Religious group & 337 & 24.7 \\
\hline 3 & Educational group & 384 & 28.1 \\
\hline 4 & Community/neighbourhood village & 586 & 42.9 \\
\hline 5 & Gender based groups & 599 & 43.9 \\
\hline 6 & Ethnic, Family or Kin/Age group & 978 & 71.5 \\
\hline
\end{tabular}

Source: Onyemenam; (2017).

Consequently, perceived household benefits from membership of and participation in informal and or formal groups are likely to be influenced by their 'indigene status', 'age', 'occupation', 'education', 'income', 'group composition', etc. which may be constrained by households' strong ties to cultural values. Respondent households' perception of level of trust and solidarity (table 5) among community members is very strong, at $94.2 \%$ (especially on financial matters $74.2 \%$, and community leaders, $67.7 \%$ ) but $62.2 \%$ of respondents see community members as unwilling to assist when alerted, even though people are generally willing to assist (94.2\%). Also $67.9 \%$ don't trust leaders of organisations at the community - a general negative disposition, which challenges the role of multiple formal networks in

Table 4: Households Most Preferred Groups Networks

\begin{tabular}{|l|c|c|}
\hline & & Percentage (\%) \\
\hline Wame of group/networks & Frequency (N) & 54.6 \\
\hline Anioma union & 740 & 54.8 \\
\hline Village/neighbourhoods association & 748 & 66.8 \\
\hline Credit/Savings/finance group & 913 & 68.6 \\
\hline Farming/fishermen & 937 & 72.0 \\
\hline Religious group & 984 & 73.5 \\
\hline Political groups/ associations and party & 1004 & 75.0 \\
\hline Town union/Youth/Age-grade groups & 1024 & 79.6 \\
\hline Traders association/businesses & 1082 & 81.1 \\
\hline Cooperative society & 1108 & 90.8 \\
\hline
\end{tabular}

Source: Onyemenam, (2017)

social capital formation and appropriation by households for their benefits. Most respondents (table 6) do not trust the community-level organisations or its leaders (67.9\%), however, they trust the local government and its officials (government structure closest to them) and state government and its officials (71.6\%). Indeed, 48.3\% say they do not trust the Federal Government while another 39.2\% were indifferent, suggesting a deep lack of trust in the Federal Government. Respondents had different 'trust levels' over selected agencies of government operating within their community $-78.9 \%$ lack trust in the Nigerian Police Force and its officials, 63.6\% trust educational institutions and the teachers, $61.8 \%$ trust medical institutions and their officials. 
Table 5: Households' perception of Community Trust and Solidarity

\begin{tabular}{|c|l|c|}
\hline $\mathbf{S} / \mathbf{N}$ & Perception Indices (N=1,366) & Frequency (N) /(\%) \\
\hline 1 & Most People are Trustworthy & \\
\hline & a. People can be trusted & $1,287(94.2 \%)$ \\
\hline & b. You can't be too careful & $79(5.8 \%)$ \\
\hline 2 & There is Community/Village, Neighbourhood Trust and Solidarity & \\
\hline & a. Agree Strongly & $895(65.5 \%)$ \\
\hline & b. Agree Somewhat & $471(34.5 \%)$ \\
\hline 3 & Willingness To Help When Alerted & $79(5.8 \%)$ \\
\hline & a. Agree Strongly & $224(16.4 \%)$ \\
\hline & b. Neither Agree nor Disagree & $850(62.2 \%)$ \\
\hline & c. Disagree & $213(15.6 \%)$ \\
\hline & d. Strongly Disagree & $351(25.7 \%)$ \\
\hline & Willingness to Assist in community/village & $936(68.5 \%)$ \\
\hline & a. Strongly Agree & $79(5.8 \%)$ \\
\hline & b. Agree Somewhat & $79(5.8 \%)$ \\
\hline 5 & c. Disagree & $273(20.0 \%)$ \\
\hline & No Trust in Matters of Lending or Borrowing & $935(68.4 \%)$ \\
\hline & a. Agree Somewhat & \\
\hline & b. Neither Agree nor Disagree & \\
\hline & c. Disagree & \\
\hline
\end{tabular}

\section{Source: Onyemenam}

This is important in understanding and explaining the relationship between government intervention schemes, organisational social capital and household welfare since 'trust' and 'participation' are essential to the successful implementation of state interventions and the positive impact on household welfare

\section{Perception of Organisational Social Capital}

Two measures were used. First, the Narayan \& Pritchett (1999) seven-dimensions proximate measure for organisational (structural) social capital - Density of membership (number of organisations household belong to), Homogeneity/Heterogeneity (do you belong to an organisation with similar/different membership background), Benefits (derived from membership and participation), Contributions (in cash

Table 6: Households' Level of Trust in Institutions/ Officials.

\begin{tabular}{|c|l|c|c|c|c|}
\hline S/N & $\begin{array}{l}\text { Level of Trust in } \\
\text { Institutions/Officials (N -1,366) }\end{array}$ & Do not Trust & $\begin{array}{l}\text { Neither small/ } \\
\text { great extent }\end{array}$ & $\begin{array}{l}\text { Trust to great/very } \\
\text { great Extent }\end{array}$ & $\begin{array}{l}\text { Non- } \\
\text { Response }\end{array}$ \\
\hline 1 & Trust Community Leaders & $74(5.4 \%)$ & $337(24.7)$ & $924(67.7 \%)$ & $31(2.3 \%)$ \\
\hline & $\begin{array}{l}\text { Community Level } \\
\text { Organisations/Officials }\end{array}$ & $321(23.5 \%)$ & $606(44.4 \%)$ & $418(30.6 \%)$ & $21(1.5 \%)$ \\
\hline 3 & Local Government/ Officials & $88(6.4 \%)$ & $506(37 \%)$ & $709(51.9 \%)$ & $63(4.6 \%)$ \\
\hline 4 & State Government/ Officials & $17(1.1 \%)$ & $313(22.9 \%)$ & $978(71.6 \%)$ & $58(4.2 \%)$ \\
\hline 5 & Federal Government/ Officials & $660(48.3 \%)$ & $536(39.2 \%)$ & $112(7.9 \%)$ & $57(4.25)$ \\
\hline 6 & Nigerian Police/ Officials & $360(26.4 \%)$ & $731(53.5 \%$ & $248(18.1 \%)$ & $2(2 \%)$ \\
\hline 7 & All School Teachers & $106(7.8 \%)$ & $355(26 \%)$ & $869(63.6 \%)$ & $36(2.6 \%)$ \\
\hline 8 & Medical Personnel (Nurses/Doctors) & $49(3.6 \%)$ & $445(32.6 \%)$ & $844(61.8 \%)$ & $28(2.0 \%)$ \\
\hline
\end{tabular}

Sources: Onyemenam, (2017).

and or kind) Attendance at Meetings (as measure of active participation), Effectiveness of organisation (perception of how well it does its job), Decision-making, (do you have a say in the affairs of the organisation?). A high score on any of each component measured (using the Likert scale) denote a high amount of that component of social capital and therefore membership benefits 
Table 7: Households Perception of Organisational Social Capital

\begin{tabular}{|c|l|c|c|}
\hline S/N & Social Capital Components & Frequency (N) & Percentage (\%) \\
\hline 1 & Density of Membership & 1,112 & 81.4 \\
\hline 2 & Heterogeneity & 1,018 & 74.6 \\
\hline 3 & Benefits & 1,303 & 95.4 \\
\hline 4 & Contributions & 1,259 & 92.1 \\
\hline 5 & Attendance at Meetings & 1366 & 100 \\
\hline 6 & Effectiveness Of Organization & 1,112 & 81.4 \\
\hline 7 & Decision-Making & 1,034 & 75.7 \\
\hline
\end{tabular}

Source: Onyemenam, (2017).

to the household. Respondents affirmed membership of (81.4\%) and strong participation in $(100 \%)$ the activities of formal organisations (table 7), which they do benefit immensely from. This corroborates assumptions and findings in the literature of a positive relationship between organisational social capital and household welfare albeit without an explicit reference to the role of 'less institutionalised networks and social relations', beyond the simplistic incorporation in the analytical models.

\section{Perception of Cognitive Social Capital}

The second measure focused more on the informal, 'social' and 'cultural' components of social capital that is of interest to this study (table 8) namely, the 'groups and networks,' 'collective action and cooperation', 'source of information and communication', 'conflict and violence', 'trust and solidarity', 'social cohesion and inclusion', and 'empowerment and political action'. Evidently most households have 'close friends' (61.20\%), with 'similar economic status' (66.20\%), who they 'believe are ready to help' (94.40\%), especially during 'long-term emergencies' (100\%), described as 'disaster' on 'farmland' or 'harvest loss'. There is a 'strong level of trust' (94.20\%) that breeds 'its own kind of reliable assistance' (94.20\%), strongest at the 'nuclear family/lineage level' and at the level of 'close friends' (86.30\%). It begins to weaken towards the 'community-level' (65.5\%). Expectedly, there is a 'strong feeling of togetherness'/closeness' (78\%) (since they are worthy of the same status - 71.60\%), that encourages 'participation in communal functions' $(61.60 \%)$ and 'reduces the chances that differences will cause problems' (50.70\%) hence the 'strong level of social cohesion', 'sociability and inclusion' observed in their responses.

Respondent households (97.00\%) participate frequently in community activities (86.40\%), voluntarily (69.30\%), especially the problem-solving type, even in times of serious personal affliction. 'Town criers' - traditional way of making announcements to indigenes - $(88.20 \%)$, was the second most preferred source of information (Radio and Television - 93.30\%) and communities were adjudged generally very peaceful $(86.10 \%)$, free from criminal activities and violence $(83.50 \%)$ even during the time of political activities $(79.80 \%)$, with a general feeling of happiness (87.60\%), which facilitated participation in socio-political activities like attending village meetings $(83.70 \%)$ and taking part in the political process $(68.40 \%)$ including being able to make decisions concerning themselves (81.40\%). All these are a strong indication of value consensus, capacity for collective and cooperative activism and a potentially high level of 'bonding social capital', which is consistent with findings of ethnographic studies on the Anioma people - the unifying effect of cultural beliefs passed on from one generation another, over time. 
Table 8: Perception of Dimensions of Social Capital.

\begin{tabular}{|c|c|c|}
\hline Structural/Cognitive Social Capital Indices & $\begin{array}{l}\text { Frequencies } \\
\text { (N) }\end{array}$ & $\begin{array}{c}\text { Percentages } \\
(\%)\end{array}$ \\
\hline $\begin{array}{l}\text { Groups and Networks } \\
\text { a. } \text { Close friends } \\
\text { b. Help when in sudden need } \\
\text { c. Similar economic status } \\
\text { d. Long-term/emergency need }\end{array}$ & $\begin{array}{c}991 \\
1,289 \\
904 \\
1,366\end{array}$ & $\begin{array}{c}61.20 \\
94.40 \\
66.20 \\
100.00 \\
\end{array}$ \\
\hline $\begin{array}{l}\text { Trust and Solidarity } \\
\text { a. People can be trusted } \\
\text { b. Most people can be trusted } \\
\text { c. People willing to offer help } \\
\boldsymbol{d} \text {. Trust people of same ethnic group } \\
\boldsymbol{e} \text {. Trust people of other ethnic group }\end{array}$ & $\begin{array}{c}1,287 \\
895 \\
1,287 \\
1,179 \\
561\end{array}$ & $\begin{array}{l}94.20 \\
65.50 \\
94.20 \\
86.30 \\
41.10\end{array}$ \\
\hline $\begin{array}{l}\text { Social Cohesion and Inclusion } \\
\text { a. Strong feeling of togetherness and closeness } \\
\text { b. Low socio-economic differences } \\
\boldsymbol{c} \text {. Whether differences caused problems } \\
\text { d.Participated in function of a public/social nature }\end{array}$ & $\begin{array}{c}1,080 \\
977 \\
693 \\
841\end{array}$ & $\begin{array}{l}78.00 \\
71.60 \\
50.70 \\
61.60\end{array}$ \\
\hline $\begin{array}{l}\text { Collective Action and Cooperation } \\
\boldsymbol{a} \text {. Household participation in community activities } \\
\boldsymbol{b} \text {. Frequency of participation } \\
\boldsymbol{c} \text {. Voluntary participation } \\
\boldsymbol{d} \text {. Problem solving activity } \\
\boldsymbol{e} \text {. In times of serious personal affliction/need } \\
\quad \text { i. Somewhat/Very likely } \\
\quad \text { ii. Neither likely/Unlikely } \\
\end{array}$ & $\begin{array}{c}1,325 \\
1,044 \\
946 \\
1,010 \\
1,102 \\
129 \\
\end{array}$ & $\begin{array}{l}97.00 \\
86.40 \\
69.30 \\
73.90 \\
\\
80.70 \\
17.60 \\
\end{array}$ \\
\hline $\begin{array}{l}\text { Sources of Information and Communication } \\
\text { a. Most important: Radio, TV } \\
\text { b. } \text { nd - TV/Radio } \\
\text { c. } \text { 3rd }^{\text {rd }} \text {-friends, Relatives } \\
\text { d. Newspaper }\end{array}$ & $\begin{array}{c}1,275 \\
1,205 \\
708 \\
307 \\
\end{array}$ & $\begin{array}{l}93.30 \\
88.20 \\
51.90 \\
22.50 \\
\end{array}$ \\
\hline $\begin{array}{l}\text { Conflict and Violence } \\
\text { a. Community is very peaceful and safe from crime } \\
\text { b. Free from criminal activities and violence } \\
\text { c. Can walk the streets alone and free any time }\end{array}$ & $\begin{array}{l}1,176 \\
1,140 \\
1,090\end{array}$ & $\begin{array}{l}86.10 \\
83.50 \\
79.80 \\
\end{array}$ \\
\hline $\begin{array}{l}\text { Empowerment and Political Action } \\
\text { a. Perception of decision- making about self } \\
\text { b. Happiness perception index } \\
\text { c. Involved in socio-political action: } \\
\text { i. Attend village meeting } \\
\text { ii. Involved in political activity (campaign, etc) } \\
\text { iii. Participated in riots, strike } \\
\text { iv. Alerted by newspaper radio/TV to local } \\
\text { problem }\end{array}$ & $\begin{array}{c}1,112 \\
1,196 \\
1,144 \\
934 \\
257 \\
442\end{array}$ & $\begin{array}{l}81.40 \\
87.60 \\
\\
83.70 \\
68.40 \\
18.80 \\
32.40\end{array}$ \\
\hline
\end{tabular}

Source: Onyemenam, (2017)

\section{Household Welfare Indicators}

The proximate measure for 'household welfare' included 'access facilitation' to eight components of household welfare (table 9), which showed that most respondents viewed access to 'education' as the strongest benefit (71.5\%), followed by 'agricultural input' (64.6\%), 'safe drinking water, public taps and/or sanitation' (63.8\%), 'credit/savings schemes' (59.5\%) and 'health' (54.4\%). 'Opportunities for travelling' and 'family support' (as narrowly defined) were seen as less significant, even though this might have overlapped with 'scholarships', 'credit/savings support', etc. 
Table 9: Households' Perception of Access to Welfare Indices

\begin{tabular}{|c|l|c|c|}
\hline S/N & Household Access Categories & Frequencies (N) & Percentages (\%) \\
\hline 1 & $\begin{array}{l}\text { Education /Training or } \\
\text { Apprenticeship/Scholarships }\end{array}$ & 977 & 71.5 \\
\hline 2 & $\begin{array}{l}\text { Agricultural input (technology, } \\
\text { fertilizer, procurement) }\end{array}$ & 882 & 64.6 \\
\hline 3 & $\begin{array}{l}\text { Water supply/borehole, public } \\
\text { taps, sanitation. }\end{array}$ & 871 & 63.8 \\
\hline 4 & $\begin{array}{l}\text { Financial: Credit/Savings Schemes, } \\
\text { Cooperative society. }\end{array}$ & 813 & 59.5 \\
\hline 6 & $\begin{array}{l}\text { Health services (midwife/first } \\
\text { aid/dispensary, etc.) }\end{array}$ & 743 & 54.4 \\
\hline & $\begin{array}{l}\text { Family support-e.g. NAPEP, grants, allowances, food } \\
\text { subsidy (minus ext. remittances) }\end{array}$ & 692 & 50.7 \\
\hline 6 & Traveling- (local and abroad) & 643 & 47.1 \\
\hline
\end{tabular}

Source: Onyemenam; (2017).

Most respondents (60\%) benefited from informal loans, savings and credit scheme - 'esusu', credit purchase and other benefits made available by cooperative societies and micro finance institutions operating in the area with their 'social identity' as members of a kin group, a savings scheme (esusu), or women's association, etc., as enough 'collateral'.

\section{Social Capital and Welfare Benefits}

The top three most identified benefits (figure 2) by households were 'medical assistance and benefits', 'financial support' and 'socialisation, (including family support and social anchorage'). Others were 'spiritual', 'recognition', 'information sharing and leisure-giving functions' and obtaining of favour.

Figure 2: Benefits of Membership in Groups.

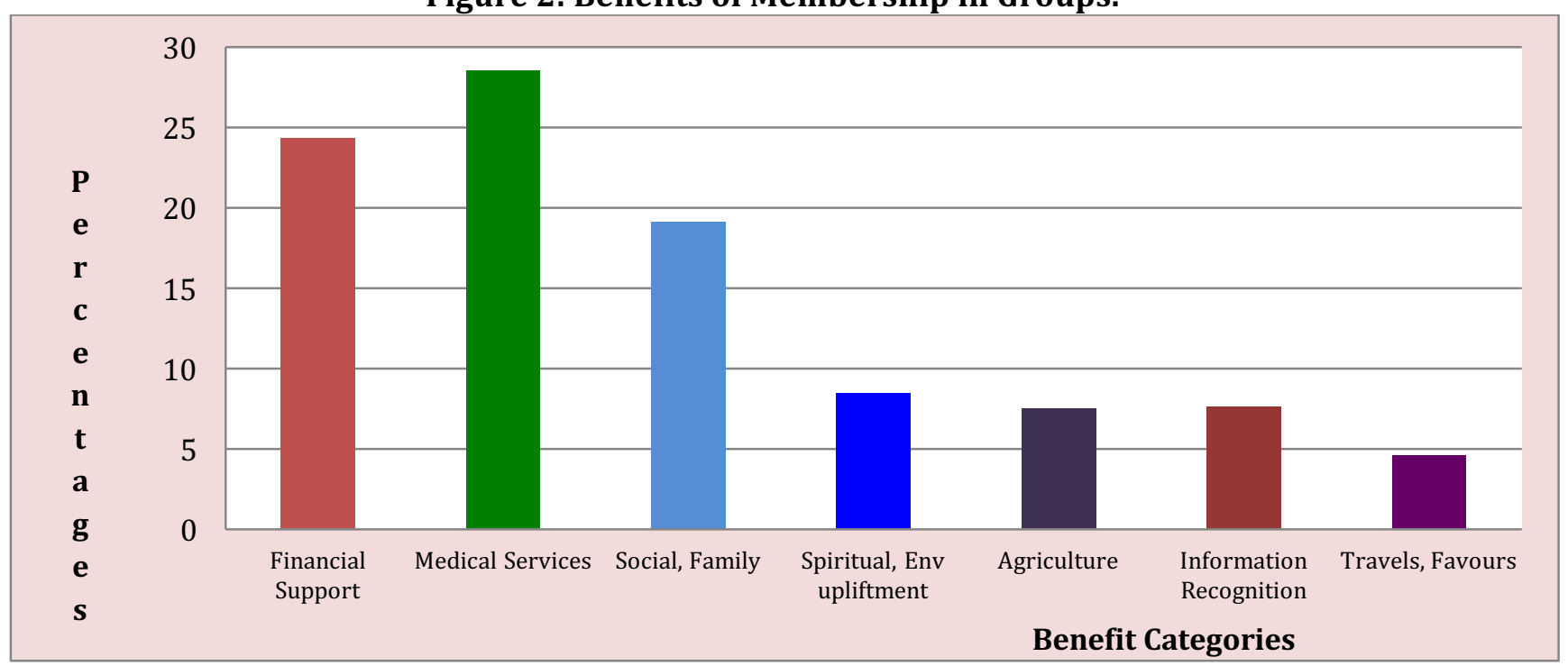

Source: Onyemenam, (2017).

\section{Hypotheses Evaluation}

Five hypotheses were evaluated. The first hypothesis states that there is a relationship between access to social capital and sex of head of household. Put differently, do households headed by men have greater access than those headed by women (or vice versa)? Data on access to components of household welfare were cross-tabulated with sex gender. The result of the chi-square statistical test, $\mathrm{x}^{2}$ was 0.390 and at a p-value of 0.532 , there is no significant relationship between the sex of the head of the household and access to social capital. This is 
consistent with the fairly evenly distributed gender of respondents. The second hypothesis states that households with high income are more likely to benefit from high social cohesion and inclusion. The data on monthly income was used as proxy for household per capita income and the two categories of 'low' and 'high' social cohesion and inclusion' were constructed from the survey data. The result of the chi square test, $\chi^{2}$, was 19.392 and at a p-value of 0.000 , there is a significant relationship between household income and social cohesion and inclusion. The Spearman's rho, at $r=0.115$, means a significant correlation between per capita income and social cohesion and inclusion. Although $22.1 \%$ of the respondent households in the 'low income' category had 'high' social cohesion and inclusion, 35.6\% in the 'medium income' category had 'high' social cohesion and inclusion and of those in the 'high income' category, $31.3 \%$ had 'high' social cohesion and inclusion. Households with the 'highest' scores of social cohesion and inclusion are in the 'medium income' category. The third hypothesis states that social network is positively correlated with household welfare. Data on the categories of social network index were cross-tabulated with the categories of household welfare index earlier constructed. The result of the chi-square test, $\chi^{2}$, was 3.054 and with a p-value of 0.217 , there is no significant relationship between social network and household welfare. Among respondent households with 'high social network,' 63\% had 'low welfare' status while among those with 'medium social network,' $62 \%$ had 'low welfare' status. Among respondent households with 'low social network,' $57 \%$ had 'low welfare' status. There is thus no statistical evidence to support the hypothesis at all. The same pattern is observed in relation to socioeconomic and demographic characteristics of the respondents. While this suggests that households with 'low welfare status' have better social network than those with 'high' and 'medium' welfare status, the association is not significant due to factors in their social history. The fourth hypothesis states that there is a relationship between a household's stock of social capital and its welfare. Data on the categories of 'low' and 'high' stock of social capital and the categories of 'low' and 'high' household welfare status, were used and the chi-square test, $\chi^{2}$, was 1.373 and with a pvalue of 0.241 , there is no significant relationship between a household's stock of social capital and its welfare. Of the $61.0 \%$ respondents categorised to have 'low' stock of social capital, $59.4 \%$ have 'low' household welfare while $62.4 \%$ have 'high' household welfare. Of the $39 \%$ with 'high' stock of social capital, $40.6 \%$ have 'low' welfare status, while $37.6 \%$ have 'high' welfare status, an indication that the relationship, if at all, is not significant. This is consistent with Meagher's (2006), findings in her study of the manufacturing sector in the southeast, Nigeria. The fifth hypothesis states that there is a relationship between social capital and household per capita income. Data on the categories of social capital and household per capita income were used and the result of the chi-square test, $\chi^{2}$, was 14.481 , and with a $p$-value of 0.001, there is a significant relationship between social capital and household per capita income. The Pearson correlation test at $r=0.230$, also shows that it is a positive correlation (significant at the 0.000 level). Out of the 434 households with 'low' monthly household income (less than N20,000.00), 52.3\% reported 'low social capital,' while, of the 418 households in the 'medium' monthly income category,(N20,001.40,000.00), 241 or $57.7 \%$ reported 'high social capital' and of the 246 respondent households in the 'highest income category' (N40,001.00 to N50,000.00+), 151 or $61.4 \%$ reported 'high' social capital category. Baiyegunhi (2013), Akinleye \& Majekodunmi (2012) also reached the same conclusion in their respective studies.

\section{DISCUSSION}

This study showed that access to social capital is not sex sensitive - gender does not necessarily constrain access to social capital among the Anioma people generally. This is contrary to the conjecture that male household heads will have greater access to social capital than female household heads. The familiar cliché that females are typically marginalised and therefore expected to experience some disadvantage, is not the case here. Ethnographic data showed 
that Anioma women were moulded by experiences of historical events and social facts not only to be as independent and 'individualistic' as the men - their migratory background, years of inter-tribal wars, local conflicts and working out consensual peaceful co-existence with neighbours - played a vital role that helped them to live up to the role of head of household. Also, the massive socioeconomic and demographic effects of the male massacre during the civil war were quite overwhelming. It manifested in worsening poverty and increase in the number of female household heads. The widows suddenly had the headship of their households thrust upon them due to the generational, man-inflicted incident. Family/kin group support and cultural values provided the vital springboard for them to live up to their new roles, thus obviating any potential sex based advantage. Their social history confirmed a strong culture of 'rotating-credit' market women groups along deep sub-ethnic lines, which extended credits and access to finance without collateral - only their active membership of the group was sufficient. The individualism that pervades the communities and the egalitarian nature helped inspire the female-headed households to survive/succeed on their own. This finding is contrary to that of Ijioma \& Osondu (2015), in their study of farm households in Enugu State, Nigeria, where male farm household heads achieved higher levels of social capital than their female counterparts and Christoforou's (2005) study that showed that women tended to have a lower social capital (participation level). Whilst the coefficient of association in the former study was strong, at 1.639 and statistically significant at 1\% probability level, the later study showed a weak association and since these were based on econometric models alone, the nature of the associations and underlying factors in the informal social milieu, which could lead to a different conclusion, were clearly not given adequate consideration. Olawuyi \& Oladele (2012) observed a similar pattern in their study, although with a predominantly female sample size - in all their 3 models, sex was found not to be sensitive. Also, Abdul-Hakim, Ismail \& Abdul-Razak (2010) in their study of the impact of social capital on quality of life in Malaysia, found out that sex is not significant in explaining quality of life - using similar household welfare indicators as in this study. But Myers \& Diener (1995) discovered that subjective wellbeing is evenly distributed with sex, race, age, socioeconomic status, and wealth. Thus, the seeming inconclusive nature of the relationship in these studies, based on econometric analyses, could have been resolved by reference to their social history as in this study.

On the significant relationship between households with high income and benefits from social cohesion and inclusion, the findings revealed a curvilinear pattern. It shows that social cohesion and inclusion is highest for medium income families - households that do not have financial power and those with very high financial power are likely to score lower on the social cohesion and inclusion index than those with medium per capita income. Digo, Koros \& Everlyne (2014) and Baiyegunhi (2013), reached the same position in their respective (econometric) studies. However, in this study, ethnographic data revealed how they have become a highly cohesive and homogenous amalgamation of communities by their active participation in various kinship-based activities (through which tremendous informal social capital is generated and appropriated), which have engendered strong bonding and 'cult-like' attachment to cultural beliefs and communal values. They include such networks founded on cultural beliefs as the 'esusu', 'age-grade' and 'peer' groups, traditional ceremonies like 'burial rites', 'marriage', 'child naming', 'communal land ownership', 'farming practices' and collective actions to support one another in times of disaster or poor harvest. The intensity of interaction fans the embers of social cohesion and inclusion, deepens the self-reinforcing, voluntary submission to communal and kinship values and the pressure that places a communal obligation on households who have more than others, to give - to 'be your brother's keeper' such that often, their 'being rich' becomes a 'burden of some sort'. 
Ironically, the voluntary discharge of these obligations and the understanding that one can be assisted when in need and or ostracised (punishment) for unacceptable conduct, elicits submission to and makes 'cultural beliefs and communal values' important, even if indirect, but effective tools that foster social control, social cohesion and inclusion. It is evident in the community social structure (and is expressed in the popular cliché that 'onye nwe nmadu kaa onye nwe ego' - literally translated, means if you have someone, you are better than the person who has money) and supports the view that social cohesion and inclusion is driven more by communal and kinship values and are vital ingredients that foster the right social milieu for economic prosperity among the rural poor households. Also, further analysis showed that although per capita income is correlated with social cohesion and inclusion, there were no differences in impact when investigated against sex of head of household but seemed to hold true against educational attainment. The study found that social network and household welfare are not associated - people with strong social networks among the Anioma people were not likely to enjoy better welfare as defined in this study. Ethnographic data reveal that formal social networks play a very limited role because of the near stranglehold of communal values on households, which have reduced the importance of formal, community-level organisations.

One assumption of social capital is that it is built during positive interactions, which occur for several reasons. Put differently, social capital resources, when not utilised, is depleted and so with a negative disposition towards the leaders of community level organisations and an intense interaction within the denser kinship-based groups, household welfare would not have been significantly impacted by community-level organisations. The informal, responsive and adaptive capacities of kinship groups recommend them easily to households - they were closest, required no registration formalities, involve a high level of trust and solidarity, willingness to assist and were deeply embedded in the communities' social structure - makes it hardly possible for formal community-level organisations to be relevant. Hu \& Jones (2004) found such ethnographic influence in their study also. However, Adepoju \& Oni (2012), Anyiro (2015) and a few others found formal networks to be instrumental in improving the welfare of rural households, based on econometric models that did not adequately incorporate the sociological aspects and their dynamics within the wider social milieu as espoused in this study.

The study showed that there was no significant relationship between a household's stock of social capital and its welfare. While there was a strong relationship between household per capita income and social capital - the way a household's stock of social capital is appropriated to enhance its welfare is the major reason - households have to contend with the obligations placed on them by the communal value of being your brother's keeper it had subscribed to, in the appropriation of its stock of social capital. This oftentimes poses a huge 'moral burden' on the household's social capital situation and ultimately, the dynamics of the community's poverty level and development process. Thus, where the stock of social capital is high, rather than appropriate it exclusively for its own benefits, the typical household is obliged to assist the kinship member who is in need, most times, first, while considering its own 'welfare improvements'. The obligations toward kinship members reinforce primordial sentiments and allegiance to communal values, fosters deeper social cohesion and inclusion while further diminishing the role of formal organisations. This is often reflected in their attitude towards these organisations especially during meetings, where the tendency assumes a 'conflictual' dimension, especially when personal predilections overshadow collective interest. Given the high level of poverty among the Anioma people (Okidegbe, 2001, Osia, 2012), the stock of social capital soon became somewhat of a burden to the well-connected or high-income earner. This explained why household welfare remained low/poor, in spite of their high stock of social 
capital. This finding is not in sync with those of Yusuf (2008) and Adi (2006) that equated high household per capita income with improvements in household welfare (including those that used household per capita expenditure as a measure of social capital).

Finally, the study showed that there is a significant relationship between social capital and household income. Baiyegunhi, (2013), Akinleye \& Majekodunmi (2012), Olawuyi \& Olawuyi (2015) all reached similar conclusions in their respective studies. However, the strong relationship did not translate into significant improvement in household welfare due to the impact of communal obligations on the appropriation of the stock of social capital of highincome earners. This is the rationale for labelling social capital in this context, as a 'burden', a sort of 'draw back', rather than an enhancement factor to them. This finding has pitched the role of (the two types of) social capital of less institutionalised networks and social relations against organisational social capital in the contemporary development and policy literature. Thus where organisational social capital is held to (or not to) be significantly related to household welfare, the relationship should be further investigated (as in this study) to see if the social capital that inheres in less institutionalised networks and social relations (informal social capital) supports the view or is useful in explaining the intervening factor(s), (if any, as in this study - poverty level) to the extent that reveals any further extraneous factor(s) (in this case, the obligations to give, emanating from the communal values). In this study, the use of ethnographic data helped to establish the high level of poverty that reduced the impact of informal social capital on the enhancement of the welfare of households with a high stock of social capital and/or a high household per capita income.

In the same vein it is noted that culturally enshrined levels of individualism, moderated by cultural values and communal standards of egalitarianism, social apprehension of being labelled as 'often resorting to communal assets for support', and the possible eroding of personal pride that comes along with it, are some of the reasons why people resort more to kinship ties and groups than formal, community-level organisations, for assistance. Furthermore, the study found that age of head of households is positively related to the level of participation in activities of kinship-based groups - perhaps due to the impact of those historical events - however, this finding is consistent with those of Ijioma \& Osondu (2015), in their study of farm households in Enugu. It is also partly due to a cherished desire by the elderly who often preside over these groups, to guide the younger ones, preserve communal and cultural assets and ensure that tradition and customs are 'passed on' to younger generations properly. Besides, with age, people get relatively more mature and have a greater chance of achieving a higher level of social capital formation and appropriation as demonstrated by Akpabio, (2008), Olawuyi \& Olawuyi, (2015), Atemnkeng \& Vukenkeng, (2016) and Rustiadi \& Nasution, (2017).

\section{CONCLUSION}

This study investigated the relationship between social capital and household welfare. Unlike most studies that used econometric modelling and focused on formal social capital, it used a non-econometric, cross-sectional survey approach complemented with ethnographic data and provided evidence that social capital of informal networks and social relations play an important role in enhancing household welfare of the rural poor. Informal networks and social relations can be significant in the successful implementation of government poverty interventions towards promoting 'bottom-up' led economic growth and social development. The study examined organisational (formal) social capital and social capital of informal networks and social relations. Ethnographic data was used to extend the analysis by incorporating useful insights from the social history of the study population and how the 
resultant social milieu impact rural poor household welfare and community social development. Although a significant relationship was found between components of organisational social capital and household welfare, the relationship between informal social capital and household welfare was not demonstrated essentially because the level of poverty among the people was high and the appropriation of the household's stock of social capital was influenced by the communal value that places an obligation on those who have more than others, to assist those in need - 'be thy brother's keeper', - such that their 'high stock of social capital' did not translate into enhanced welfare. Thus, where 'rich households' demonstrated higher stock levels of social capital (in terms of the dimensions of organisational social capital and informal social capital), there was no significant household welfare enhancement. If the analysis had stopped at this point, the findings about the relationship would be, to say the least misleading. Ethnographic data has revealed a positive relationship, which had been moderated into near insignificance by the pervasive poverty and the impact of communal obligations on 'rich' households, on how they appropriated their stock of social capital and the strong social cohesion and inclusion it engendered. This confirms the role of community social characteristics, especially how it has ebbed interest in formal organisations typically relied upon to deliver government and donor agencies' poverty interventions and therefore, inadvertently, how they undermine their existence and the success of such projects. Consequently, and as ethnographic data has established, social capital of informal networks and social relations play important pivotal role in enhancing the welfare of the rural poor households. They may be less institutionalised, but they are durable and relied upon more by the poor rural households. Integrating formal organisations and kinship groups into government poverty interventions will therefore foster significant household-level participation, especially when it is based on a clear definition of social capital that see them, not as 'anti-development', but as vital traditional sources of capital to the rural poor and 'facilitators' of community-driven development. They represent the first line of proactive actions to stem the tide in rural-urban migration and so policies that integrate them into the development process are important.

Government should promote action research, effective communication, and invest in both formal and informal social capital as part of its poverty strategy. This would foster the orderly development of such organisations and kinship groups, ensure adequate support to and strengthening of existing ones, not because they are 'social capital' by themselves, but they are the 'vehicle' for delivering 'social capital' - active involvement and participation of rural poor households. In this respect, Government's financial sector interventions to improve the rural poor households' access to credit should incorporate the kinship groups who often serve as provider of 'credit of last resort' to 'one of their own', based on their common 'social or ethnic identity' and the age-old tradition of extending such credits. This would ultimately enhance household access to such credits as part of a poverty intervention and community-driven development strategy. Conscious of their 'family name' and communal obligations to 'conform', informal networks and social relations have become important tools for galvanising active participation of the rural poor households in 'bottom-up' community development, which can facilitate the achievement of sustainable development goals (SDGs). 


\section{References}

Abdul-Hakim, R., Ismail, R. \& Abdul-Razak, N. A. (2010). “The Impact of Social Capital on Quality of Life: Evidence from Malaysia." Ontario International Development Agency, Canada.

Adepoju, A.A. \& Oni, O.A. (2012). "Investigating Endogeneity: Effects of Social Capital on Household Welfare in Nigeria: A Control Function Approach." Quarterly Journal of International Agriculture, 51(1): 73-96.

Adi, A.B.C. (2006). "The Organisational Social Capital of Community Development Organizations in South East Nigeria". Mimeo 267, Japan University of Tokyo.

Akinbode S.O., Hamzat; S. G. (2017). "Women Asset Ownership and Household Poverty in Rural Nigeria”. Journal of Studies in Social Sciences, 16, 1: 45-64

Akinleye, 0. \& Majekodunmi, A. (2012). "Determinants of Social Capital and Sundry Variables on Household Wellbeing in South-western Nigeria." International Journal of Advanced Research in Management and Social Sciences 1(1): 17- 34.

Akpabio, I. A. (2008). "Significant Predictors of Social Capital in Farmers Organisation in Akwa Ibom State Nigeria". Journal of International Social Research 1: 61- 68.

Anyiro, C. 0. (2015). "The Effect of Social Capital on Access to Micro Credit Among Rural Farming Households in Abia State, Nigeria". Agrosearch, 15, 1: 59 - 75.

Anyiro, C.O., Ajuka P.N., Emerole, C.0, \& Orji, E.I. (2014). “Determinants of Women's Participation in Self Help Group Led Micro-Financing of Farms in Isuikwuato Local Government Area of Abia State, Nigeria Scientific Papers Series Management, Economic Engineering in Agriculture and Rural Development. 14 (3): 21-30.

Anyiro, C.O, Ezeh, C.I \& Emerole C.O (2014): “Social Capital Dimensions and Microcredit Influence on Poverty. Saarbrucken, Germany: Lambert Academic Publishing GmbH.

Anyiro, C. O. \& Ajuka; P. N. (2014). "Level of Access to Social Capital and Its Predictors Among Rural Farming Households in Abia State, Nigeria”. In Journal of Agricultural Research and Development. 13(1): 10-24.

Asa, U. A. \& Archibong, E.M. (2016). "Social Capital and Food Security Among Rural Farming Households in Akwa Ibom State, Nigeria”. Journal of Advances in Social Sciences and Humanities. 2:2: $15-19$.

Atemnkeng, J. (2009). “Does Social Capital Determine Poverty? Evidence From Cameroon Household Survey”. Presentation at the Global Network for Economics of Learning, Innovation and Competence Building Systems Conference (GLOBELICS): UNU-MERIT (Maastricht, the Netherlands) CRES, UCAD (Dakar Senegal, October 6 - 8.

Atemnkeng; J. T. \& Vukenkeng; A. W. (2016): “Does Social Capital Really Determine Poverty? Evidence from a Cameroon Household Survey. African Journal of Science, Technology, Innovation and Development, 8 1: 97-110

Baiyegunhi, L.J.S. (2013). "Rural Households' Social Capital and Welfare: A Case Study of Msinga, Kwazulu-Natal, South Africa”. Journal of Agriculture and Rural Development in the Tropics and Sub-Tropic 114, (2): $123-132$.

Balogun, O. L. \& Yusuf, S. A. (2011). "Determinants of Demand for Microcredit Among Rural Households in South-Western States, Nigeria." Journal of Agriculture and Social Sciences 7: 41-48.

Balogun, O. L. Yusuf, S. A., Omonona, B. T. \& Okoruwa, V. O. (2011). “Social Capital and Microcredit Effects on Poverty Among the Rural Households in South- Western States, Nigeria. Journal of Agricultural and Biological Science. 6 (3): 521-533.

Bourdieu, P. (1985). "The Social Space and the Genesis of Groups.” Theory and Society. 14 (6): 723-744.

Caarl, K., Fransen, S., \& Ruben, R. (2013). “Can Migratory Contacts And Remittances Contribute to Reconciliation And Reconstruction in Rwanda?" International Migration, 51(1): 98 - 117.

Christoforou, A. (2005). “On the Determinants of Social Capital in Greece Compared to Countries of the European Union” FEEM Working Paper No. 68.

Digo, C. A., Koros, D., \& Everlyne, M. M.(2014). "Household Food Security Among Women in Groups in Kaiti Division, Kenya". Asian Journal of Agricultural Sciences. 6 (1): 1 - 5.

Estes, J. (2004). “The Social Capital Mix: Core Institutions and Civil Society.” Unpublished Power Point Presentation, University of Pennsylvania. USA.

Fransen, S. (2015). "Remittances, Bonds and Bridges: and Social Capital in Burundi, The Journal of Development Studies, DOI: 10.1080/00220388.2015. 
Greif, A. (1994). "Cultural Beliefs and the Organization of Society: A Historical and Theoretical Reflection on Collectivist and Individualist Societies," Journal of Political Economy, 105 (5): 912-950.

Grootaert, C. (1998). "Social Capital, The Missing Link?” Social Capital Initiative Working Paper 3. Washington, DC: World Bank.

Grootaert, C. (1999). “Social Capital, Household Welfare, and Poverty in Indonesia.” World Bank Policy Research Working Paper 2148. Washington, DC: World Bank.

Halpern, D. (2005). “Social Capital.” Cambridge: Polity Press.

Hu, C \& Jones, B. (2004). “An Investigation into the Relationship Between Household Welfare and Social Capital in Eastern Uganda". USA: USAID, Saga Publications.

Idris, A., \& Agbim, K. (2015): “Effect of Social Capital on Poverty Alleviation: A Study of Women Entrepreneurs in Nasarawa State, Nigeria”. www.ajol.info/journals/jorind retrieved May 9th, 2017.

Ijioma, J. C. \& Osondu, K. C. (2015): “Social Capital Participation Levels and Determinants Among Farm Households in Enugu State, Nigeria." Mycopath 13 (1): 43 - 49.

Isichei, E. (1973). "A History of lgbo People”. London: Longman Publishers.

Ismawan, B. (2000). "Micro-Finance, Poverty and Social Capital." Paper 15. Presented at the Asian Regional Conference jointly organized by INASIA and CDF on "The Potential and Limitations of Economic Initiatives in Grassroots Development - Current Issues and Asian Experiences': 27th - 30th November 2000 at Rajendrapur, Bangladesh.

Knack, S. \& Keefer, P. (1997). “Does Social Capital Have an Economic Payoff? A Cross-Country Investigation”. The Quarterly Journal of Economics, 112 (4): 1251-1288.

Kumar; S. (2015): "Social Capital and Poverty: A Case Study of Household Welfare in Rural Punjab”. Unpublished Ph.D. Thesis, Department of Economics, University of Punjab, India.

Lin, N. (2001). "Building a Network Theory of Social Capital”. In Social Science Research. 3-30. New York: Aldine.

Meagher, K. (2006). "Social Capital, Social Liabilities, and Political Capital: Social Networks and Informal

Manufacturing in Nigeria." African Affairs, 105 (421): 553-582.

Myers, D.G. \& Diener, E. D. (1995). “Who is Happy” Journal of Psychological Science 6 (1): 10 - 19.

Narayan, D., \& Pritchett, L. (1997). "Cents and Sociability: Household Income and Social Capital in Rural Tanzania”. World Bank Policy Research Working Paper No. 1796. Washington DC: World Bank.

Narayan, D. \& Pritchett, L. (1999). “Social Capital: Evidence and Implications.” In Serageldin, I. (Ed). Social Capital: A Multifaceted Perspective. 269- 296. Washington, DC: World Bank.

National Bureau of Statistics (2011). “Annual Abstract of Statistics.” Abuja, Nigeria: National Bureau of Statistics.

National Bureau of Statistics (2012). "Annual Abstract of Statistics.” Abuja, Nigeria: National Bureau of Statistics.

National Bureau of Statistics (2016). "The Millennium Development Goals Performance Tracking Survey 2015

Report." Abuja, Nigeria: National Bureau of Statistics.

National Bureau of Statistics (2017). “Annual Abstract of Statistics.” Abuja, Nigeria: National Bureau of Statistics.

National Population Commission (2007). “2006 Provisional Population Census Figures”. Abuja: Nigeria: National Population Commision.

Ninalowo, A. O. (2007). “On the Crisis of Development”. Lagos: Prime Publishers.

Ninalowo; A. O. (2010). The State Qua State as Antidote to Failure: A Sociological Inquiry into Underdevelopment. Inaugural Lecture Series. Lagos, University of Lagos Press.

Ohadike, D.C. (1994). “Anioma: A Social History of the Western Igbo People." Athens: Ohio University Press. Ohadike, D.C. (1991). "The Ekumeku Movement: Western Igbo Resistance to British Conquest of Nigeria, 1883-1914". Athens, USA: Ohio University Press.

Okidegbe, N. (2001). "Poverty and Underdevelopment in Anioma". In Osia, K. (Ed). Anioma in Contemporary Nigeria: Issues in Identity and Development. Ibadan, Nigeria: BookBuilders, Editions Africa.

Okocha, E. (2006). “Blood on The Niger”. USA: Berkeley University, Press. 
Okunmadewa, F.Y., Yusuf, S.A. \& Omonona, B.T. (2005). "Social Capital and Poverty in Nigeria". Draft Final Report submitted to African Economic Research Consortium (AERC) Kenya.

Olawuyi, O.S \& Oladele, S. E. (2012). "Social Capital and Rural Household Welfare in Surulere Local Government Area Oyo State, Nigeria." Inter-disciplinary Journal of Contemporary Research in Business. 3 (11): 388-405.

Olawuyi, S. O. \& Olawuyi, T. D. (2015). "Social Capital Formation: The Missing link Among Food Crops Farmers in Osun State, Nigeria". Journal of Emerging Trends in Economics and Management Sciences 6(7): 181-189.

Onyemenam, C. 'E (2017). "Social Capital and Household Welfare Among the Anioma People in Delta State, Nigeria". Unpublished Ph. D. Thesis, Department of Sociology, University of Lagos, Nigeria.

Osia, K. (2012). "Anioma Ethnic Identity" In Osia, K. (Ed). Anioma in Contemporary Nigeria: Issues of Identity And Development. Ibadan, Nigeria: BookBuilders, Eds Africa.

Portes, A. (1998). "Social Capital: Its Origins and Applications in Modern Sociology." Annual Review of Sociology. 24:1-25.

Putnam, R. (1993). "Making Democracy Work: Civic Traditions in Modern Italy". Princeton, NJ: Princeton University Press.

Putnam, R. (2001). "Bowling Alone: The Collapse and Revival of American Community". New York: Touchstone.

Rustiadi, E. \& Nasution; A. (2017) “Can Social Capital Investment Reduce Poverty in Rural Indonesia?”. International Journal of Economics and Financial Issues. 7 (2): 109 -117.

Sama, M.C., Chiatii; E. A., Aquilas; N. A. \& Abit; O. M. (2016): "Building Social Capital In the Fishery Communities of the South-Western Region of Cameroon: The Case Of Limbe Municipality" Asian Journal of Agriculture and Rural Development, 6 (7): 119-130.

Tendler, J. (1997). “Good Government in the Tropics”. Baltimore: John Hopkins University Press.

United Nations Development Programme (2015): “Human Development Report for 2015”. NY. USA.

United Nations Development Programme (2016): “Human Development Report for 2016”. NY. USA.

Vitolas, C. A. T. (2011). "Social Capital in Poor Communities: A Case Study from Rural Northern Peru." Unpublished $\mathrm{Ph}$. D. Thesis, London School of Economics and Political Science.

Woolcock, M. and Narayan, D. (2000). "Social Capital: Implications for Development Theory, Research, and Policy". The World Bank Research Observer, 15 (2) 225 - 249.

World Bank (1999).“World Development Report 1999-2000. “International Bank for Reconstruction and Development, The World Bank Group, Washington DC.

World Bank (2001)“World Development Report 2000/2001. Attacking Poverty.” NY: Oxford University Press.

World Bank (2018). “World Development Report 2016/2017, International Bank for Reconstruction and Development The World Bank Group, Washington DC.

Yusuf, S.A. (2008). "Social Capital and Household Welfare in Kwara State, Nigeria." Journal of Human Ecology, 23 (3) 219-229. 